\title{
COMPARISON OF RESPONSE REACTION OF PINUS SYLVESTRIS L. AFTER FIRE IN HYLOCOMIOSA AND VACCINIOSA TURF. MEL.
}

\author{
Lāsma Freimane, Olga Miezīte \\ Latvia University of Agriculture \\ lasma_freimane@inbox.lv
}

\begin{abstract}
Forest fires in Latvia occur every year. Research about vegetation and forest regeneration after forest fire is being carried out in Latvia, and sanitary conditions are being evaluated too; however, there are no large studies about the forest fire impact on radial growth dynamics of trees. The aim of the study was to analyse and compare the response reaction of a forest stand after fire in two forest site types - Hylocomiosa and Vacciniosa turf. mel. The object of the research was fire affected middle-aged managed Scots pine (Pinus sylvestris L.) stands in the aforementioned forest site types. The study compares radial growth dynamics of trees, tree mortality and forest stand sanitary conditions after fire in Hylocomiosa and Vacciniosa turf. mel. The observed fire impact on radial growth dynamics of trees was negative in both forest site types. Negative fire impact on sanitary conditions was observed, too.
\end{abstract}

Key words: forest fire, Pinus sylvestris L., forest stand sanitary conditions, growing stock after forest fire.

\section{Introduction}

Forests cover 3.07 million ha of Latvia's territory (State Forest Service, 2017 a). Forest industry plays an important role in the national economy $-20 \%$ of total country's export in 2015 was forest industry export and value added share of the forest industry in Latvia's gross domestic product in 2015 was almost $5.2 \%$ (JSC 'Latvian State Forests', 2015). One of the most common tree species is Scots pine - 34\% ha of all forests are occupied by this species (State Forest Service, 2016 a). According to the State Forest Service (2016 b, 2017 b) data, fire in forest occurs every year, the annual average area of last ten years is around 333 ha (there is no data from year 2016). According to predictions about the climate change, the situation could be even worse. It is foreseen that the average air temperature will increase during the fire danger period, and frequency of extreme hot periods, too. Moreover, it is expected that temperature will not increase evenly during the summer months, but increase most during the extremely hot periods. One more prediction about favourable conditions for forest fires - it is expected that precipitation will increase only by $0-2 \%$ during summer, or even be reduced by $10-15 \%$ (Jansons, 2012).

Fire can have both positive and negative impact. Ground vegetation biodiversity after forest fires usually increases (Marozas, Racinskas, \& Bartkevicius, 2007; Marozas et al., 2011), which might be explained with an extra nutrients, released after burning of humus layer, where most of nutrients were inaccessible for the plants before fire (Certini, 2005). Fire can have a positive effect on Scots pine radial growth dynamics on dry mineral soils, but the impact of fire on tree radial growth dynamics in peat soil is negative (Freimane et al., 2013), which might be explained with forest fire type. Subsurface fire damages tree roots more than surface fire (Freimane et al., 2013, Freimane, 2015). In Lithuania five years after low intensity surface fire on sandy soil growing middle-aged Scots pine, fire impact to tree-rings growth is not observed (Marozas et al., 2011). In Northern Italy it is observed that after severe fire tree-rings in the first year are very narrow (Beghin et al., 2011). Research carried out in Norway shows that during the first five years after forest fire the annual growth decreases, then it increases $1-20$ years after forest fire, but after 20 years it decreases again (Blanck, Rolstad, \& Storaunet, 2013). Certini (2005) pointed out that the availability of nutrients after forest fire often increases, but it is not in longterm.

Forest fire impact on tree stand is also expressed as tree mortality. Tree mortality depend on several factors - age of tree, diameter of tree, species of tree, forest fire type, intensity and duration. Older Scots pine trees are more resistant to fire than younger; in the young Scots pine stands were observed higher mortality after low intensity surface fire (Sidoroff et al., 2007; Piha, 2011). It is found out that tree diameter is one more factor which affect tree resistance against fire (Fernandes et al., 2008; Donis et al., 2010; Piha, 2011, Freimane et al., 2013). Tree species are next factor which determine tree viability after fire. Comparing fire resistance of three most common tree species in Latvia - Scots pine, Norway spruce (Picea abies (L.) Karst.) and silver birch (Betula pendula Roth) - most resistant is Scots pine (Donis et al., 2010). It could be explained with its thick crust bark. Forest fire type, intensity and duration also determine tree viability after forest fire (Freimane, 2015).

Fire influence the forest stand sanitary conditions negatively, mostly insect damages are observed (Donis et al., 2010, Freimane et al., 2013, Freimane, 2015), but there is observed quite a lot cracked bark to trees growing on dried peat soil (Freimane et al., 2013). Cracked bark opens up unprotected wood which is bounded by wood lumps and formed in the result of mechanical abrasion of bark, as well as in the 
result of fire (Вакин, Полубояринов, \& Соловьев, 1980).

The aim of research was to analyse and compare response reaction of the forest stand after fire in two forest site types - Hylocomiosa and Vacciniosa turf. mel.

\section{Materials and Methods}

Research was carried out in Latvia, Zemgale district. Empirical data was collected at the end of vegetation period of 2012 and 2014 in managed middle-aged Scots pine stands - three growing in the forest site type Hylocomiosa (data collected in 2014, coordinates of the forest stand No. 1 - latitude 56.60991, longitude 23.81109, forest stand No. 2 latitude 56.60599, longitude 23.66905, forest stand No. 3 - latitude 56.940588, longitude 23.925927) and one stand in forest site type Vacciniosa turf. mel. (data collected in 2012, coordinates of forest stand latitude 56.63839, longitude 23.88408). In forest site type Hylocomiosa three circular sample plots in every forest stand were placed in the part unaffected by fire (control plots) and two sample plots were placed in the part of forest stand affected by fire, in forest site type Vacciniosa turf. mel. - five sample plots in the part of stand affected by fire, five - in unaffected by fire. Size of each sample plot was $500 \mathrm{~m}^{2}$.

For this study, the impact on tree radial growth dynamics was evaluated six years after the forest fire. Forest fire type in Hylocomiosa - low (height of scorching up to $0.5 \mathrm{~m}$ ) to medium (height of scorching from 0.5 to $1.5 \mathrm{~m}$ ) intensity surface fire, but in Vacciniosa turf. mel. - severe (height of scorching more than $1.5 \mathrm{~m}$ ) intensity surface fire and shallow (depth up to $0.25 \mathrm{~m}$ ) subsurface fire (Roga, 1979; Bušs \& Vanags, 1987).

Kraft class for every tree was determined in every sample plot (Miezite et al., 2013). Tree diameter at $1.3 \mathrm{~m}$ height above root collar was measured in the forest stands both affected and unaffected by fire. Peat layer measuring (with measuring rod) was done in Vacciniosa turf.mel.
To describe the forest fire impact on forest stand radial growth dynamics, 20 dominant stand fire affected trees and 60 fire unaffected trees were bored with Presler increment borer (I, II and III Kraft class trees) towards the sample plot center at $1.3 \mathrm{~m}$ height from tree root collar, for bored trees the tree height was measured (Liepa et al., 2013). The collected wood samples were dried at room temperature and then sanded. Tree-ring widths were measured with Lin TAB microscope system. Forest fire impact on radial growth and fire impact effect was analysed using method for evaluation of the impact of environmental factors. The method is based on comparison of tree-ring widths in environmental factor affected and unaffected forest stand (Liepa \& Zaḷkalns, 2014).

For the evaluation of the tree stand sanitary conditions after fire, the maximum height of scorching was measured. Trees with insect damage, exposed roots, cracked barks were listed.

The collected data were processed mathematically and analyzed using Microsoft Office. Statistical significance was tested by ANOVA and t-Test: Paired Two Sample for Means.

\section{Results and Discussion}

After analysis of measured tree-ring widths, it was found that first six years after forest fire treering widths are narrower than before fire occurred in both forest site types Hylocomiosa and Vacciniosa turf. mel. It is a reason for negative effect of forest fire impact (Fig. 1). In the first year after forest fire in forest site type Hylocomiosa the growing stock losses are $0.7 \mathrm{~m}^{3} \mathrm{ha}^{-1}$, over the next four years | it is approximately $1.8 \mathrm{~m}^{3} \mathrm{ha}^{-1}$ per year, and then in the sixth year $-9 \mathrm{~m}^{3} \mathrm{ha}^{-1}$. The average loss of growing stock per year is $1.5 \mathrm{~m}^{3} \mathrm{ha}^{-1}$. A longer period is needed after fire for better evaluation. It might be that in the first year after fire trees have stress, but later situation becomes better and positive impact of forest fire might be observed. For more objective explanation of fire impact on tree-ring widths and

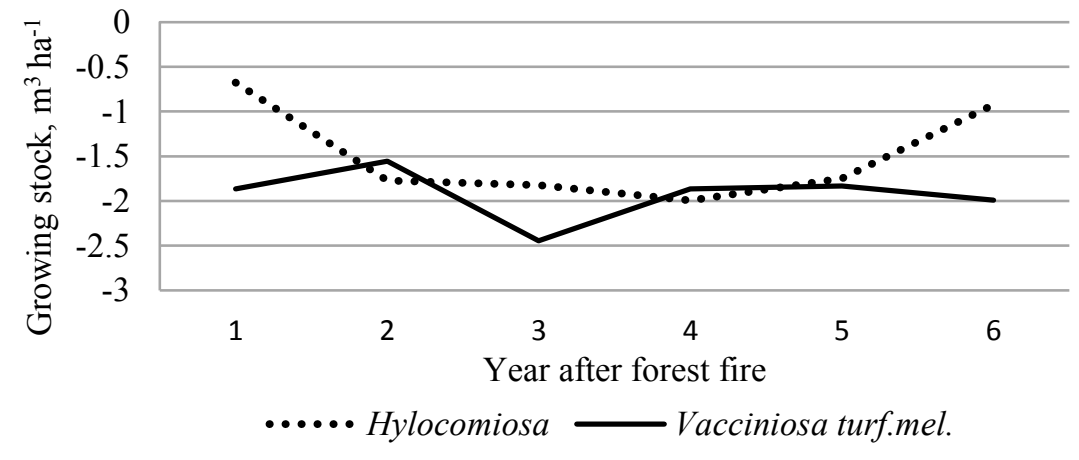

Figure 1. Effect of forest fire impact on growing stock. 


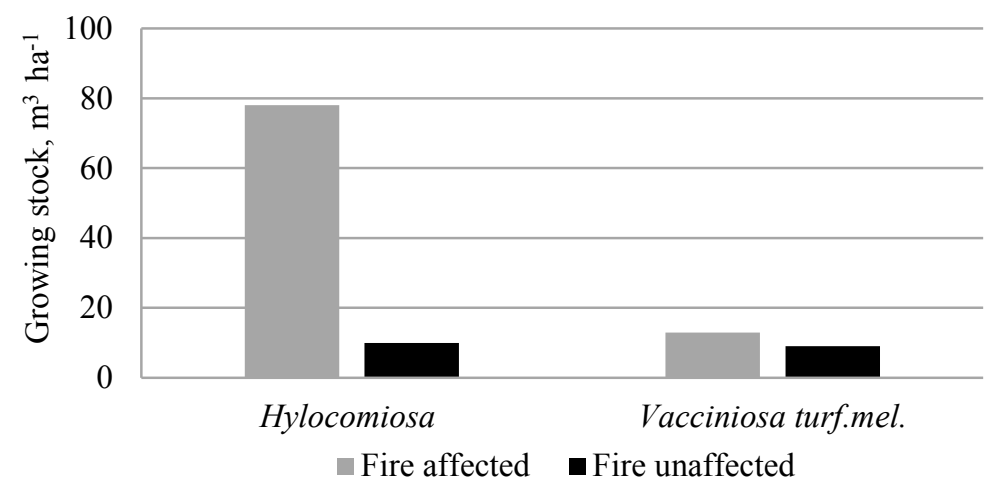

Figure 2. Tree mortality $\left(\mathrm{m}^{3} \mathrm{ha}^{-1}\right)$ in fire affected and unaffected forest area in forest site type Hylocomiosa and Vacciniosa turf. mel.

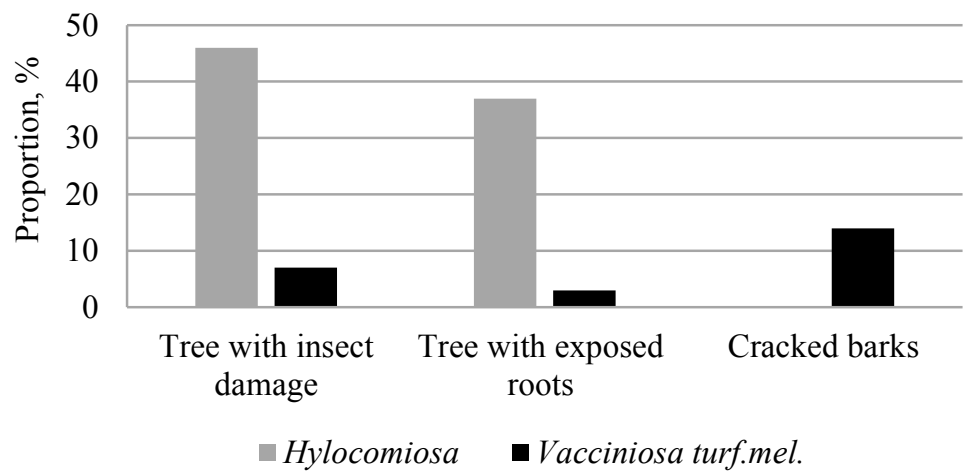

Figure 3. Type of damage and proportion in fire affected stands in forest site type Hylocomiosa and Vacciniosa turf. mel.

growing stock of middle-aged Scots pine growing in forest site type Hylocomiosa and Vacciniosa turf. mel. a larger study is needed. Research carried out by Marozas et al. (2011) shows that low intensity forest fire does not impact tree-ring growth within five years after fire.

In forest site type Vacciniosa turf. mel. the average loss of growing stock was higher $-2 \mathrm{~m}^{3} \mathrm{ha}^{-1}$ per year. And the situation improvement was not observed in the sixth year, which could mean that fire impact on tree-ring widths and growing stock in Vacciniosa turf. mel. is more negative than in Hylocomiosa.

Tree mortality was observed in both forest site types Hylocomiosa and Vacciniosa turf. mel. (Fig. 2). Tree mortality after fire is also mentioned in literature (Sidoroff et al., 2007; Piha, 2011; Eriksson et al., 2013). In forest site type Hylocomiosa the tree mortality in fire affected part was higher than in Vacciniosa turf. mel., respectively $78 \mathrm{~m}^{3} \mathrm{ha}^{-1}$ and $13 \mathrm{~m}^{3} \mathrm{ha}^{-1}$ on average, but in fire unaffected part the tree mortality was more or less the same - $10 \mathrm{~m}^{3} \mathrm{ha}^{-1}$ (in Hylocomiosa) and $9 \mathrm{~m}^{3} \mathrm{ha}^{-1}$ (in Vacciniosa turf. mel.). In both forest site types there was no significant difference between tree mortality in fire affected and unaffected parts (in Hylocomiosa $\mathrm{p}>0.05$, in Vacciniosa turf. mel. $\mathrm{p}>0.05)$, but for more objective evaluation a larger data set is needed.

The impact of fire on the forest stand sanitary conditions was negative. Figure 3 shows three different damages and their proportion of all measured trees in the fire affected stands. Trees with insect damages $(46 \%$ of all fire affected trees in Hylocomiosa, 7\% in Vacciniosa turf. mel.) and exposed roots $(37 \%$ in Hylocomiosa and $3 \%$ in Vacciniosa turf. mel.) were observed in both forest site types, but cracked bark (14\% of all fire affected trees) only in Vacciniosa turf. mel. It could be explained with forest site type, fire intensity (severe surface fire, average scorching height $2.2 \mathrm{~m}$ ) and fire type, too (surface fire plus subsurface fire). The reason of a quite high difference between proportion of trees with insect damages in Hylocomiosa and Vacciniosa turf. mel. could be possible because of insect occurrence in certain tree stands in Hylocomiosa before forest fire.

\section{Conclusions}

Research results show that forest fire does not impact tree radial growth dynamic positively in forest site types Hylocomiosa and Vacciniosa turf. mel. 
There are no significant differences between fire affected and unaffected tree mortality in forest site types Hylocomiosa $(\mathrm{p}>0.05)$ and Vacciniosa turf. mel. $(\mathrm{p}>0.05)$.

Fire had a negative impact on forest stand sanitary conditions in both forest site types. Trees with insects and exposed roots were observed both in Hylocomiosa and Vacciniosa turf. mel., but craced bark only in Vacciniosa turf. mel.

\section{References}

1. Beghin, R., Cherubini, P., Battipaglia, G., Siegwolf, R., Saurer, M., \& Bovio G. (2011). Tree-ring growth and stable isotopes $\left({ }^{13} \mathrm{C}\right.$ and $\left.{ }^{15} \mathrm{~N}\right)$ detect effects of wildfires on tree physiological processes in Pinus sylvestris L. Trees. 25(4), 627 - 636. DOI: 10.1007/s00468-011-0539-9.

2. Blanck, Y.L., Rolstad, J., \& Storaunet, K.O. (2013). Low- to moderate-severity historical fires promoted high tree growth in a boreal Scots pine forest of Norway. Scandinavian Journal of Forest Research. 28(2), 126 - 135. DOI: 10.1080/02827581.2012.706635.

3. Bušs, M., \& Vanags, J. (1987). Latvijas meži (Forests of Latvia). Rīga: Avots. (in Latvian).

4. Certini, G. (2005). Effects of fire on properties of forest soils: a review. Oecologia. 143(1), 1 - 10. DOI: 10.1007/s00442-004-1788-8.

5. Donis, J., Bičevskis, M., Zdors, L., \& Šņepsts, G. (2010). Meža ugunsgrēka ietekmes uz koka dzīvotspēju novērtēšanas metodikas izstrāde. Gala atskaite. (Methodology creation of assessment of forest fire effects on tree survival. Final Report). Retrieved October 20, 2015, from: http://www.lvm.lv/images/lvm/parskatsuguns10v2.pdf. (in Latvian).

6. Eriksson, A.M., Olsson, J., Jonsson, B.G., Toivanen, S., \& Edman, M. (2013). Effects of restoration fire on dead wood heterogeneity and availability in three Pinus sylvestris forests in Sweden. Silva Fennica. 47(2), 1 - 15. DOI: $10.14214 /$ sf.954.

7. Fernandes, P.M., Vega, J.A., Jiménez, E., \& Rigolot, E. (2008). Fire resistance of European pines. Forest Ecology and Management. 256(3), 246 - 255. DOI:10.1016/j.foreco.2008.04.032.

8. Freimane, L. (2015). Parastās priedes Pinus sylvestris L. atsauces reakcija pēc meža ugunsgrēka damaksnī Hylocomiosa (Response reaction of Scots pine Pinus sylvestris L. after forest fire in forest site type Hylocomiosa). Unpublished master thesis, Latvia University of Agriculture, Jelgava, Latvia. (in Latvian).

9. Freimane, L., Miezīte, O., Ailts, M., Meiere, N., \& Luguza, S. (2013). Response Reaction of Scots Pine Pinus sylvestris L. after Forest Fire in Forest Site Type Vacciniosa turf. mel. In Klīve Forest District. In Rural Development 2013: Innovations and Sustainability, 28 - 29 November (Vol. 6, Book 3, pp. 272 -278). Akademija, Lithuania: Aleksandras Stulginskis University.

10. Jansons, Ā. (2012). Meža apsaimniekošana klimata izmaiņu kontekstā. Projekta pārskats (Forest management in context of climate change. Project overview). Retrieved October 20, 2015, from: http:// www.silava.lv/userfiles/file/Klim_izm_meza_apsaimn_2010.pdf. (in Latvian).

11. JSC 'Latvian State Forests' (2015). Latvijas meža nozare (Latvian forest sector). Retrieved March 12 , 2017, from: http://www.lvm.lv/sabiedribai/meza-apsaimniekosana/latvijas-meza-nozare. (in Latvian).

12. Liepa, I., Zalikals, O. (2014). The Diversity of the Environmental Impact in Kurzeme. Journal of Life Sciences. 8(7), $570-581$.

13. Liepa, I., Zaḷkals, O., Luguza, S., \& Baltmanis, R. (2013). Vides faktoru ietekmes vērtēšana (Evaluating of impact of environmental factors). Retrieved October 20, 2014, from: http://maplas.mf.llu.lv/materiali/ ILiepa_Mezzinatnes_diena.pdf. (in Latvian).

14. Marozas, V., Plaušinytė, E., Augustaitis, A., \& Kačiulytė, A. (2011). Changes of ground vegetation and tree-ring growth after surface fires in Scots pine forests. Acta Biologica Universitatis Dugavpiliensis. 11 (2), $156-162$.

15. Marozas, V., Racinskas, J., \& Bartkevicius, E. (2007). Dynamics of ground vegetation after surface fires in hemiboreal Pinus sylvestris L. Forests. Forest Ecology and Management. 250(1), 47 - 55. DOI: 10.1016/j.foreco.2007.03.008.

16. Miezīte, O., Okmanis, M., Indriksons, A., Ruba, J., Polmanis, K., \& Freimane, L. (2013). Assessment of sanitary conditions in stands of Norway spruce (Picea abies Karst.) damaged by spruce bud scale (Physokermes piceae Schrnk.). iForest - Biogeosciences and Forestry. 6(2), 73 - 78. DOI: 10.3832/ ifor0703-006.

17. Piha, A. (2011). Tree mortality, fire scars formation and regeneration 8 years after low-intensity fire in managed Pinus sylvestris stands. Master thesis, University of Helsinki, Helsinki, Finland. Retrieved 
March 8, 2017, from: https://helda.helsinki.fi/bitstream/handle/10138/28407/Progradu_AuraPiha. pdf?sequence $=1$.

18. Roga, A. (1979). Meža ugunsgrēku veidi, to dzēšanas pan̄ēmieni un taktika (Kind of forest fires, methods of clearance and tactic of it). Rīga: Lat ZTIZPI. (in Latvian).

19. Sidoroff, K., Kuuluvainen, T., Tanskanen, H., \& Vanha-Majamaa, I. (2007). Tree mortality after lowintensity prescribed fires in managed Pinus sylvestris stands in southern Finland. Scandinavian Journal of Forest Research. 22(1), 2 - 12.

20. State Forest Service (2017 a). Meža apsaimniekošana (Forest management). Retrieved March 7, 2017, from: http://www.vmd.gov.lv/valsts-meza-dienests/statiskas-lapas/-meza-apsaimniekosana-?nid=1472\#jump. (in Latvian).

21. State Forest Service (2017 b). Meža ugunsgrēku skaits pa gadiem un to skatās platības (Statistics of forest fire by year and forest affected area). Retrieved March 7, 2017, from: https://www.zm.gov.lv/public/files/ CMS_Static_Page_Doc/00/00/00/42/10/ugunsgrekuskaitspagadiem.jpg. (in Latvian).

22. State Forest Service (2016 a). Valsts meža dienesta 2015. gada publikais pārskats. Meža resursu raksturojums (State Forest Service Public Overview 2015. Forest Resource Characteristics). Retrieved March 7, 2017, from: https:/www.zm.gov.lv/public/files/CMS_Static_Page_Doc/00/00/00/84/06/ Publiskaisparskats2015.pdf, p. 7. (in Latvian).

23. State Forest Service (2016 b). Valsts meža dienesta 2015. gada publikais pārskats. Meža ugunsapsardzība (State Forest Service Public Overview 2015. Forest Fire Managment). Retrieved March 7, 2017, from: https://www.zm.gov.lv/public/files/CMS_Static_Page_Doc/00/00/00/84/06/Publiskaisparskats2015.pdf, p. 16. (in Latvian).

24. Вакин, А.Т., Полубояринов, О.И., \& Соловьев, В.А. (1980). Пороки древесины (Tre defects). Москва, Лесная промышленность, 80 - 82 с. (in Russian). 